\title{
Comparison of different bull breeding systems
}

\author{
D. FEWSON \\ Institut für Tierhaltung und Tierzüchtung der Universität Hohenheim, \\ Postfach 700562/470, D-7000 Stuttgart 70, B.R.D.
}

In the present study the results of model calculations for the efficiency of different bull breeding systems are compared.

In nearly all situations the ranking of the bull breeding systems with respect to genetic gain was starting with the best one : semen storage system, waiting-bull system. With regard to breeding profit the ranking was reversed. Limited funds for investment and high economic weights for beef traits favoured the young bull system.

\section{Genetic parameters of milk production characteristics and their use in selection indexes.}

\author{
R. TEINBERG, V. KASK
}

Institute of Experimental Biology, Academy of Sciences of the Estonian S.S.R., U.S.S.R.

The system of programs for electronic computer for calculating genetic parameters (heritability, standard deviations, phenotypic and genetic correlations) and linear selection indexes was compiled. The index for selection of cows on the basis of 7 characters was the following :

$$
\begin{gathered}
\mathrm{SI}=0.1655 \mathrm{~d}_{1}+187.3485 \mathrm{~d}_{2}+1.5746 \mathrm{~d}_{3}+121.0227 \mathrm{~d}_{4} \\
+0.2370 \mathrm{~d}_{5}+0.7454 \mathrm{~d}_{6}+41.1987 \mathrm{~d}_{7},
\end{gathered}
$$

where $d_{1} \ldots d_{7}$ are deviations of cow records from the herd average for milk yield, fat content, fat $\mathrm{kg}$, protein content, protein $\mathrm{kg}$, body mass and milkability $(\mathrm{kg} / \mathrm{min})$ respectively.

\section{Prerequisites for carrying out cattle breeding programmes in breeders' associations}

\author{
H. MOMM \\ Institut für Tierhaltung und Tierzüchtung der Universität Hohenheim, \\ 7000 Stuttgart 70, Bundesrepublik Deutschland
}

Centralized breeding programmes are increasingly in cattle breeding. Within breeders' associations these programmes depend on a number of member-breeders or live-stock owners. That is why the problem of acceptance of the centralized programme by member-breeders arises.

This paper presents an outline pointing out the prerequisites which lead to a solution of the problem ; it is meant to be a contribution to improve carrying our of breeding programmes. According to the outline the main prerequisites are a combination of the instruments of organization, information and motivation. A suggestion is made in view of further investigations into these instruments. 